\title{
KERNFORSCHUNGSZENTRUM
}

\author{
KARLSRUHE
}

Mai/November 1968

KFK 779

Institut für Strahlenbiologie

Metabolism of Radiocaesium during Gestation and Lactation as influenced by Ferric-cyanoferrate(II)

$$
\text { F. Havlíćek }
$$

Interaction between Chelates and Endogenous Zinc

A. Catsch, A.-E. Harmuth-Hoene, F. Havlíček, S. Carpy

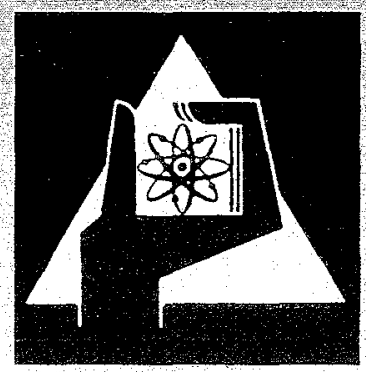

GESELLSCHAFT FUR KERNFORSCHUNG M.B.H. 


\section{Metabolism of Radiocaesium during Gestation and Lactation as influenced by Ferric-cyanoferrate(II)}

IT HAS been shown that oral administration of ferriccyanoferrate(II) (FGF) leads to a diminished enteral reabsorption of radiocaesium and, thus, to a marked reduction of the body burden. ${ }^{(1-6)}$ The present study is concerned with the effect of FCF in rats during gestation and lactation.

The animals of the first group were injected intraperitoneally with carrier-free ${ }^{137} \mathrm{CsCl}$ two days prior to mating, those of the second group immediately after parturition. Unmated rats served as control. One half of each group was maintained on a standard diet, the other one on pellets with 1 per cent FGF. The retention of ${ }^{137} \mathrm{Cs}$ was assayed during 3 weeks after the injection by means of a whole-body counter.

In all experimental groups, the dependence of ${ }^{137} \mathrm{Gs}-$ retention upon time is given by the sum of two exponentials: $R_{t}=a_{1} \exp \left(-\lambda_{1} t\right)+a_{2} \exp \left(-\lambda_{2} t\right)$, where $\lambda_{1}$ amounts to $\sim 0.7$. The following conclusions can be drawn from the data compiled in the table:

\begin{tabular}{ccccl}
\hline Group & FGF & $a_{1}$ & $a_{2}$ & \multicolumn{1}{c}{$\lambda_{2}$} \\
\hline (1) unmated & - & 24 & 76 & 0.0633 \\
(2) unmated & + & 50 & 50 & 0.116 \\
(3) gestation & - & 26 & 74 & 0.0775 \\
(4) gestation & + & 46 & 54 & 0.134 \\
(5) lactation & - & 44 & 56 & 0.124 \\
(6) lactation & + & 68 & 32 & 0.183 \\
\hline
\end{tabular}

(i) FGF is highly effective in decreasing the fraction as well as the half-time of the second term of the retention function.

(ii) The excretion of ${ }^{137} \mathrm{Cs}$ is enhanced during gestation (in addition to the marked placental transfer) and, in particular, during lactation.

(iii) The comparison between the accumulation of ${ }^{137} \mathrm{Cs}$ in the litters and the "apparent" cumulative excretion with milk (as calculated from the data of the Table) shows that the diminished retention in lactating rats is only partly due to the excretion with milk. Rather a generally enhanced turnover has to be assumed.

(iv) There is a complete additivity between the effect of FCF and that of gestation and lactation, respectively.

A more detailed description and discussion of the experiments are given elsewhere ${ }^{(7)}$.

Institut für Strahlenbiologie

F. HAVLIČ́EK

Kernforschungszentrum Karlsruhe,

Germany

\section{References}

1. Nigrović V. Int. J. Radiat. Biol. 7, 307 (1963).

2. Nigrović V., Bohne F. and Madshus K. Strahlentherapie 130, 413 (1966).

3. Nigrović V. Phys. Med. Biol. 10, 81 (1965).

4. Madshus K., Strömme A., Bohne F. and Nigrović V. Int. J. Radiat. Biol. 10, 519 (1966).

5. Richmond C. R. and Bunde D. E. Proc. Soc. expt. Biol. Med. 121, 664 (1966).

6. Havliček F., Kleisner I., Dvořák P. and PosPí IL J. Strahlentherapie 131, 123 (1968).

7. HAvličEK F. studia biophys. 3, 239 (1967). 


\title{
INTERACTION BETWEEN CHELATES AND ENDOGENOUS ZINC
}

\author{
A. Catsch, A.-E. Harmuth-Hoene, F. HavlíčeK and S. Carpy
}

Repeated administration of the Ca-chelates of EDTA, DTPA and related compounds can give rise to toxic side-effects, mainly to nephrotic lesions. The most straightforward and likely explanation suggests an interaction between the chelating agent and essential trace metals, i.e. a disturbance of metal homeostasis which leads to an impairment of the activity of metal-controlled biological entities and functions. Which metal(s) and which biological constituents are actually involved, however, is an open question. Although the Ca-chelates lead to a marked zincuria, whereas the excretion of other trace metals is influenced, if at all, to a lesser degree (Bohne et al., 1967a; Candura et al., 1960; Millar et al., 1954; Perry and Perry, 1959; Spencer and Rosoff, 1966; Tarui, 1960; Truhaut et al., 1966), the pathogenetic relevance of these findings, however, is not yet fully understood. Our experimental contribution is concerned with some quantitative aspects of the interaction between chelating agents and endogenous $\mathrm{Zn}$.

In the first experimental series, rats were injected with carrier-free ${ }^{65} \mathrm{Zn}$ and after different time intervals (from the 7th until the 28th day) with the Ca-chelates of EDTA and DTPA. The dosage was 1,10 and $100 \mu \mathrm{mol}$ per animal, respectively. Theoretically one ought to expect a dependence of the excretion of stable $\mathrm{Zn}$ and ${ }^{65} \mathrm{Zn}$ on the value of the so-called conditional stability constant E ( $c f$. Catsch, 1964a). E can be derived from the stability of the $\mathrm{Zn}$-chelate and the dosage of the chelate; it also takes into account the competition of endogenous $\mathrm{H}^{+}$and $\mathrm{Ca}^{2+}$. Starting from this basis, we have to expect a 100-times higher effectiveness of DTPA. The plot of the urinary stable $\mathrm{Zn}$ against $\mathrm{E}$ (Fig. 1) shows that this is actually the case; with the only exception that $1 \mu \mathrm{mol}$ DTPA is markedly less effective than the equivalent dose of $100 \mu \mathrm{mol}$ EDTA. The same holds also for the urinary excretion of ${ }^{65} \mathrm{Zn}$. As can be seen in Fig. 2, its specific activity in urine depends upon the time of chelate administration and decreases with a half-time of 11 days.

The enchanced urinary excretion of $\mathrm{Zn}$ and ${ }^{65} \mathrm{Zn}$ does not necessarily imply a genuine removal of endogenous $\mathrm{Zn}$. The possibility has to be considered that the chelators exert an influence solely on the excretion route and that the higher urinary levels are compensated by a correspondingly lower faecal elimination.

In order to answer this question, the following experiment was performed: ${ }^{65} \mathrm{Zn}$ was injected and the urinary and faecal excretions of ${ }^{65} \mathrm{Zn}$ on the tenth day were determined in untreated animals, as well as after administration of 1 and $100 \mu \mathrm{mol}$ EDTA and DTPA respectively. By subtracting the control values from the excretion rates as influenced by the chelates, we obtain an estimate of the Zn-balance. Fig. 3 shows that the net excretion of ${ }^{65} \mathrm{Zn}$ is distinctly enhanced in spite of the somewhat lower faecal excretion. Since there are no cogent reasons to assume that the specific activities of ${ }^{65} \mathrm{Zn}$ excreted with the urine and into the intestine are not identical, one may conclude that we are dealing with a genuine mobilization of endogenous $\mathrm{Zn}$. Once more, the exceptional behaviour of $1 \mu \mathrm{mol}$ DTPA has to be stressed.

The question is raised as to the source of the surplus excreted $\mathrm{Zn}$. We can take it for granted that the physiological dilution space of the chelate ions is mainly confined to extracellular water (Foreman, 1960). The $\mathrm{Zn}$-content of this compartment, however, in the rat 
amounts to $0.15 \mu \mathrm{mol}$ only (Gilbert and Taylor, 1956) and is, thus, distinctly lower than the amount that can be removed by chelators. It has been shown by Bohne et al. (1967b) that DTPA does not affect the absorption of $\mathrm{Zn}$ from the gut. Consequently, the assumption that an enhanced enteral absorption accounts for the elevated excretion can be ruled out and we may conclude that the excreted $\mathrm{Zn}$ is partly supplied by the intracellular fraction of the $\mathrm{Zn}$ pool. This conjecture is in keeping with the concept that the exchange of $\mathrm{Zn}$ between the

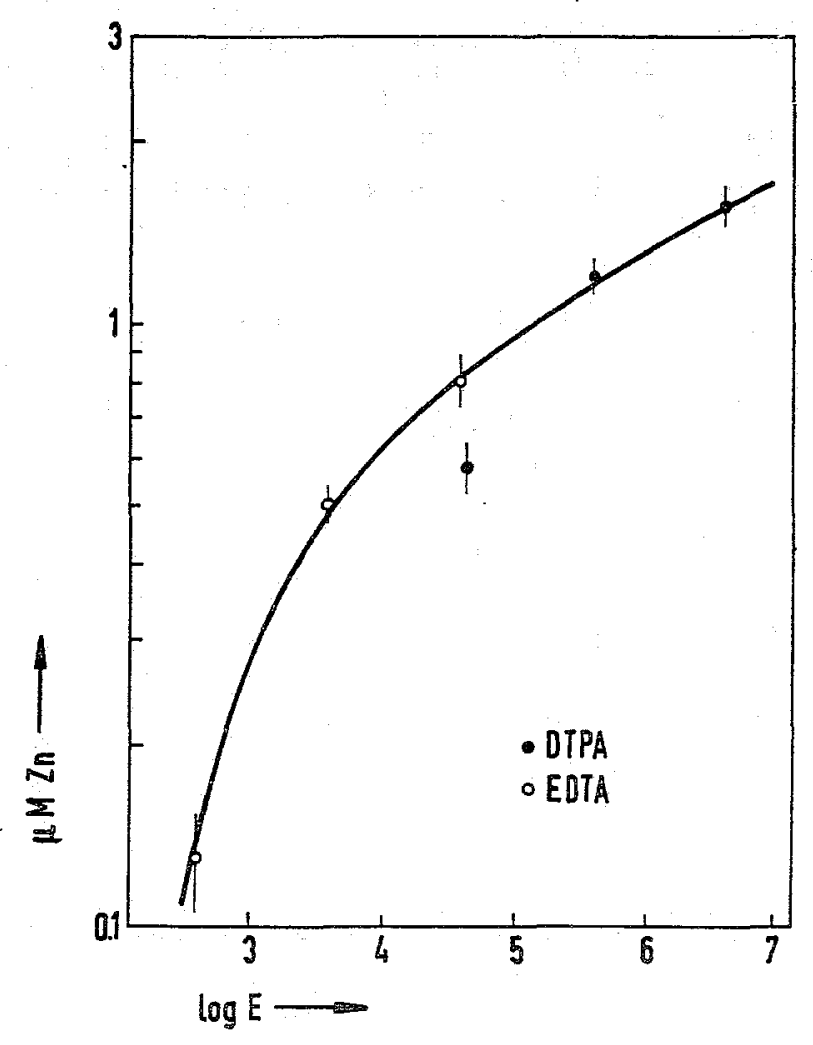

Fig. 1.

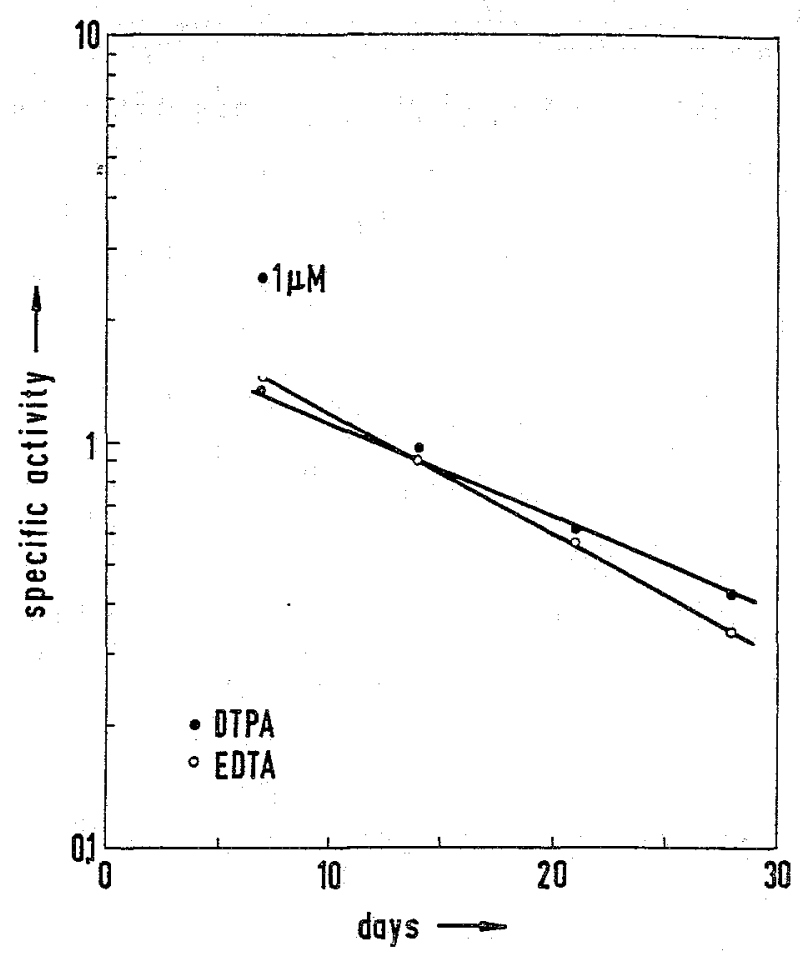

Fig. 2.

Fig. 1. Dependence of the urinary $\mathrm{Zn}$-excretion (24 hrs.) upon the conditional stability constant $\mathrm{E}$. Fiducial limits for $\mathrm{P}=.05$.

Fig. 2. Dependence of the specific activity of the urine upon the time of chelate administration.

extracellular and (at least some) intracellular compartments occurs at a relatively high rate. The statement that the chelating agents, by disturbing this equilibrium, are able to mobilize intracellular $\mathrm{Zn}$ can be made more precise: it can be assumed that the specific activities of the removed and the removable $\mathrm{Zn}$ are identical and, hence, decrease with identical half-times. The half-time of urinary ${ }^{65} \mathrm{Zn}$ amounts to 11 days (Fig. 2). The retention equations compiled by Ballou and Thompson (1961) show that for the pertinent time interval and for all organs, blood plasma included, terms with half-times $>23$ days are dominating. The only exception is the liver with a short-lived fraction (nine days). This close agreement justifies the tentative assumption that the chelates lead to a partial depletion of the $\mathrm{Zn}$-stores of the liver.

Let us now turn to the exceptional behaviour of the $1 \mu \mathrm{mol}$ DTPA-dosage. The starting point for its understanding is given by the fact that the co-ordination number of $\mathrm{Zn}^{2+}$ is 4 , whereas DTPA is an octadentate ligand so that the relatively stable bimetallic species $\mathrm{Zn}_{2}$ DTPA can be formed (Anderegg et al., 1959). In contrast to the simple 1:1-chelate, $\mathrm{Zn}_{2^{-}}$ DTPA has one negative charge only and it is, therefore, conceivable that it may penetrate cellular membranes more easily than the uninuclear species. Having entered the intracellular space of the liver, the bimetallic chelate would show a changed excretion pattern: partly it is 
excreted via the biliary route, partly - following rediffusion into the blood - by the kidneys. This assumption is consistent with our experimental results (Fig. 3). In order to explain why the net excretion of ${ }^{65} \mathrm{Zn}$ is still lower than one should anticipate on the basis of the E-value, two (experimentally substantiated) prerequisites have to be fulfilled: $(a)$ that the specific
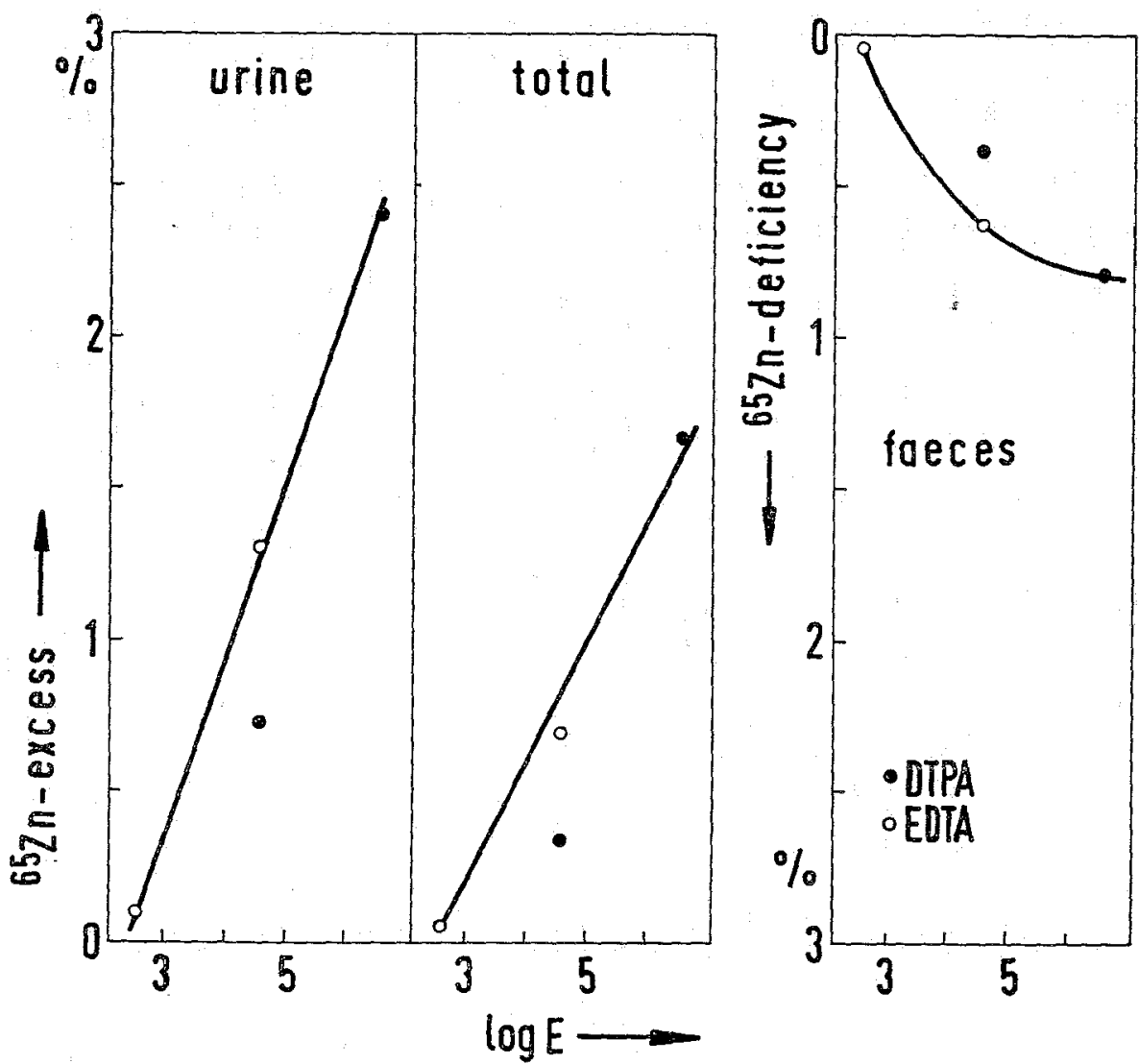

Fig. 3. Dependence of the urinary and fecal ${ }^{65} \mathrm{Zn}$-excretion (percentage of ${ }^{65} \mathrm{Zn}$-dose) upon the conditional stability constant $\mathrm{E}$.

activity of the intracellular space is lower than that of the extracellular fraction (Gilbert and Taylor, 1956) and (b) that isotopic exchange between the endogenous $\mathrm{Zn}$ and the $\mathrm{Zn}$ chelated by the ligand takes place (Catsch and Lê, 1965, 1966).

The formation of bimetallic chelates needs one essential prerequisite: the concentration of the ligand should not be largely in excess of the metal concentration, as otherwise simple 1:1-chelates would be formed preferably. Since the removable endogenous $\mathrm{Zn}$-fraction is limited, we have to deduce that this condition is fulfilled only in the case of the $1 \mu$ mol-dose.

It is self-evident why EDTA does not exhibit an anomalous behaviour. EDTA possesses 6 ligand atoms only and is, therefore, unable to form bimetallic chelates of appreciable stability.

A new parameter was incorporated in the next experiment. Three days prior to the determination of the DTPA-efficacy (in removing $\mathrm{Zn}$ and ${ }^{65} \mathrm{Zn}$ ) the rats were pre-treated with 100 $\mu \mathrm{mol}$ DTPA per day. As can be seen from Table I, the pre-treatment does not affect the effectiveness of the test-dose. Apparently, the Zn-depletion of the organism is transient only and the depleted $\mathrm{Zn}$-stores are quickly refilled with enterally absorbed $\mathrm{Zn}$ (Bohne et al., 1967b).

If one considers these results in conjunction with the finding that the effectiveness of DTPA in removing $\mathrm{Zn}$ is 100 times that of EDTA while the relative potency of DTPA with respect to chronic toxicity equates 2 only (Catsch, 1964b), it is quite obvious that one cannot simply equate toxicity with general $\mathrm{Zn}$-depletion. On the other hand, we cannot overlook the fact that $\mathrm{Zn}$ - and $\mathrm{Co}(\mathrm{II})$-chelates are definitely less toxic than Ca-chelates (Catsch, 1964b; Catsch 
and Von Wedelstaedt, 1965). This fact throws serious doubts on attempts to make the chelate ion per se responsible for the toxicity and to interpret the renal lesions as a so-called osmotic nephrosis.

Investigations of the in vitro inactivation of the $\mathrm{Zn}$-containing carbonic anhydrase show that the degree of inactivation (although it definitely is brought about by removal of $\mathrm{Zn}$ ) does

TABLE I

Urinary excretion following the administration of 100 umol DTPA on the 14th day

\begin{tabular}{ccc}
\hline $\begin{array}{c}\text { Pre-treatment on 11th-13th } \\
\text { day (100 } \mu \text { mol DTPA per day) }\end{array}$ & $\begin{array}{c}\mathrm{Zn}_{\pi} \\
(\mu \mathrm{g})\end{array}$ & $\begin{array}{c}{ }^{65} \mathrm{Zn} \\
\text { (percent of dose) }\end{array}$ \\
\hline- & $86.7 \pm 4.9$ & $0.97 \pm 0.05$ \\
+ & $82.3 \pm 4.0$ & $1.04 \pm 0.02$ \\
\hline
\end{tabular}

not correlate with the $\mathrm{Zn}$-stability constants. Furthermore, the mobilization of $\mathrm{Zn}$ is preceded by the formation of ternary complexes. In this case only a few of the electron-donoratoms of the chelating agent are involved and one cannot operate with the usual stability constants which are valid for the 1:1-chelates. We do not want to assert that the inactivation of renal carbonic anhydrase is a decisive factor in the development of nephrotoxicity. On the contrary, this particular enzyme is most definitely not involved. The findings obtained with carbonic anhydrase, however, could serve as a model in explaining the missing correlation between the toxicity of chelators and their affinity toward $\mathrm{Zn}$ and - we want to stress this point - to other trace metals as well.

In the chronic treatment situation the therapeutic index of Zn-DTPA is 10-20 times higher than that of Ca-DTPA (Catsch et al., 1964; Catsch and Von Wedelstaedt, 1965). A final recommendation of $\mathrm{Zn}-\mathrm{DTPA}$, however, cannot be made until we know whether the retention of ${ }^{65} \mathrm{Zn}$ following the administration of $\mathrm{Zn}$-DTPA (labelled with ${ }^{65} \mathrm{Zn}$ ) is due to a genuine splitting off of $\mathrm{Zn}$ and/or to isotopic exchange with endogenous $\mathrm{Zn}$. This question is crucial

\section{TABLE II}

\section{Principle of the method using ${ }^{65} \mathrm{Zn}-D T P A^{19} \mathrm{C}$}

$\mathrm{Zn}_{\text {exch }}=$ exchangeable fraction of the endogenous $\mathrm{Zn}$-pool

$Z_{\text {tot }}=$ total dose of administered $Z n$

$\mathrm{Zn}_{\mathrm{ret}}=$ retained fraction

$\mathrm{Zn}_{\mathrm{mob}}=$ mobilized fraction

\begin{tabular}{lcc}
\hline & $\begin{array}{c}\text { Injected } \\
\text { solution }\end{array}$ & Urine \\
\hline${ }^{65} \mathrm{Zn} / \mathrm{Zn}$ & $\mathrm{S}_{1}$ & $\mathrm{U}_{1}$ \\
$\mathrm{Zn} /{ }^{14} \mathrm{C}$ & $\mathrm{S}_{2}$ & $\mathrm{U}_{2}$ \\
\hline
\end{tabular}

(1) $\mathrm{Zn}_{\text {exch }}=\mathrm{Zn}_{\text {tot }}\left(\mathrm{S}_{1} / \mathrm{U}_{1}-1\right)$

(2) $Z_{n_{\text {ret } / m o b}}=Z_{n_{\text {tot }}}\left(1-U_{2} / S_{2}\right)$

positive figures of 2 : retention of $Z_{n}$

negative figures of 2: mobilization of $\mathrm{Zn}$ 
because of possible long-term side-effects of $\mathrm{Zn}$. To answer this question, we selected a method (Harmuth-Hoene et al., 1966) which uses Zn-DTPA doubly labelled with ${ }^{6} \mathrm{Zn}$ and ${ }^{14} \mathrm{C}$. The underlying principle as well as the results are given in Tables II and III. Firstly, splitting-off and retention of $\mathrm{Zn}$ have to be excluded. On the contrary, $\mathrm{Zn}$-DTPA is capable of binding and, thus, mobilizing a second Zn-Ion. Secondly, these data fully confirm our

\section{TABLE III}

Exchange, mobilization and retention of $Z n$ following administration of $Z$ Zn-DTPA. Lower and upper fiducial limits for $P=0.05$

(For further explanation see Table II)

\begin{tabular}{lrrr}
\hline & \multicolumn{3}{c}{$\mu \mathrm{mol} \mathrm{Zn}-\mathrm{DTPA}$} \\
\cline { 2 - 4 } & \multicolumn{1}{c}{1} & \multicolumn{1}{c}{10} \\
\hline $\mathrm{Zn}_{\text {exch }}(\mu \mathrm{mol})$ & $0.53 ;$ & 0.62 & $0.31 ; 1.16$ \\
$\mathrm{Zn}_{\text {ret } / \mathrm{mob}}(\mu \mathrm{mol})$ & $-0.22 ;$ & -0.42 & $-1.13 ; 0.58$ \\
\hline
\end{tabular}

earlier assumption that in the case of $1 \mu \mathrm{mol}$ DTPA the exchangeable fraction of the Zn-pool shows a significantly higher value; once more, a dependence of the metabolic pathway and the physiological dilution space upon chelate dosage is suggested.

In summarizing the results of Table III, we have no misgivings regarding the therapeutic use of $\mathrm{Zn}-\mathrm{DTPA}$ in humans.

\section{REFERENCES}

AnderegG, G., NäGeli, P., Müller, F. and Schwarzenbach, G. (1959): Komplexone XXX. Helv. chim. Acta, 42, 827.

Ballou, J. E. and Thompson, R. C. (1961): Metabolism of zinc-65 in the rat. Hlth Phys., 6, 6.

Bohne, F., HARMUth-HoEne, A.-E. and WeBER, K. M. (1967a): Vergleichende Untersuchungen über die Wirksamkeit von Chelatbildern bei der experimentellen Eisenspeicherkrankheit der Ratte. Naunyn-Schmiedebergs Arch. exp. Path. Pharmak., 257, 409.

Bohne, F., Nigrović, V. and Harmuth-Hoene, A.-E. (1967b): Metabolisches Verhalten und Toxizität therapeutischer Komplexbildner. 2. Mitteilung. Strahlentherapie. In press.

Candura, F., CANDura, M., Villa, T. and Eszechielli, S. (1960): L'eliminatione urinaria e fecale dello zinco durante trattamento con etilendiaminotetracetato calciodisodico (EDTACaNaz). Lav. Umano, $12,402$.

CATsCH, A. (1964a): Radioactive Metal Mobilization in Medicine. Ch. C. Thomas, Springfield, Ill.

CATsCH, A. (1964b): Zur Toxikologie der Diäthylentriaminpentaessigsäure. Naunyn-Schmiedebergs Arch. exp. Path. Pharmak., 246, 316.

CATSCH, A. and L̂े, D. KH. (1965): Removal of ${ }^{60} \mathrm{Co}$ and ${ }^{65} \mathrm{Zn}$ from the mammalian body. Experientia (Basel), 21, 724.

CATSCH, A. and Lề, D. KH. (1966): Das Verhalten von Radiozink-Chelaten im Säugetierorganismus. Strahlentherapie, $130,557$.

Catsch, A., LÊ, D. KH. and Chambault, D. (1964): Evaluation of the efficacy of different metal chelates of DTPA in removing internally-deposited radionuclides. Int. J. Radiat. Biol., 8, 35.

CATSCH, A. and WedelstaEdT, E. von (1965): Vergleichende Untersuchungen über die Toxizität der Ca- und Zn (II)-Chelate der Diäthylentriaminpentaessigsäure. Experientia (Basel), 21, 210.

Foreman, H. (1960): The pharmacology of some useful chelating agents. In: Metal-Binding in Medicine, p. 82. J. B. Lippincott, Philadelphia and Montreal.

GILBERT, J. G. F. and TAYLOR, D. M. (1956): The behaviour of zinc and radio-zinc in the rat. Biochim. biophys. Acta (Amst.), 21, 545. 
Harmuth-Hoene, A.-E., Catsch, A., Nigrović, V. and Bohne, F. (1966): Excretion of ${ }^{65} \mathrm{Zn}-\mathrm{DTPA}$ in the rat. Int. J. Radiat. Biol., 10, 479.

Millar, J. M., Fischer, M. I., Mawson, C. A. and Elcoate, P. V, (1954): Influence of ethylenediamine-tetraacetic acid on the excretion of zinc by the rat. Nature (Lond.), 174, 881.

Perry, H. M. and PerRY, E. F. (1959): Normal concentrations of some trace metals in human urine: Changes produced by ethylenediamine-tetraacetate. J. clin. Invest., 38, 1452.

SPENCER, H. and RosofF, B. (1966): Effect of chelating agents and the removal of zinc-65 in man. Hith Phys., 12, 475.

TARU, S. (1960): The influence of chelating agents on urinary excretion of metals. Med. J. Osaka Univ., $10,449$.

Truhaut, R., Boudène, Cl. and Lutz, M. (1966): Recherches dans la série des complexones. Ann. Biol. chim., 24, 419.

\section{DISCUSSION}

LINDENBAUM: Dr. Catsch, did you measure the activity of the carbonic anhydrase in the liver?

CATSCH: Only in the kidneys, and we have done it in vivo and in vitro. We have to use a very high concentration (about $10^{-2}$ molar), in order to get an inactivation of the carbonic anhydrase by approximately $10 \%$.

LINDENBAUM: And also, your point about the toxicity ratios for the EDTA and DTPA calcium and zinc chelates: they may not necessarily have anything to do with one another.

CATSCH: You cannot overlook the fact that DTPA is a hundred times more effective in removing zinc than EDTA, whereas its toxicity is only twice higher.

LINDENBAUM: They may be two separate things. It is interesting to consider.

CATSCH: You should expect a correlation between the two figures.

SмIтH: Doctor Catsch, when you refer to treatments using the zinc salt, I presume you do not suggest its use in the acute or prompt treatment case but recommend zinc-DTPA mainly for treatments in delayed long-term therapy?

CATSCH: I think zinc-DTPA should not be given in acute emergencies, but in our opinion it is the compound of choice in a chronic treatment situation. This means treatment for about two, three weeks, or even longer periods. 